\title{
Research Article \\ IMMUNOREACTIVE RECOMBINANT NITRATE REDUCTASE EXPRESSED BY NIR A GENE OF Mycobacterium avium sub sp paratuberculosis IS900 ELEMENT IN E.coli
}

\author{
PADMAVATHY $C .{ }^{* 1}$, VIJAYARANI K. ${ }^{2}, K_{\text {KUMANAN K. }}{ }^{3}$, THANGAVELU A. ${ }^{4}$ AND SRITHAR A. ${ }^{5}$ \\ 1/nstitute of Veterinary Preventive Medicine (IVPM), Ranipet, 632402, Vellore District, Tamil Nadu, India \\ 2Department of Animal Biotechnology, Madras Veterinary College, Tamil Nadu Veterinary and Animal Sciences University, Chennai, 600 007, Tamil Nadu, India \\ ${ }^{3}$ Centre for Animal Health Studies (CAHS), Tamil Nadu Veterinary and Animal Sciences University, Chennai, 600051 , Tamil Nadu, India \\ 4,5Department of Veterinary Microbiology, Madras Veterinary College, Tamil Nadu Veterinary and Animal Sciences University, Chennai, 600 007, Tamil Nadu, India \\ *Corresponding Author: Email-kpkumarr@rediffmail.com
}

Received: March 12, 2018; Revised: March 15, 2018; Accepted: March 16, 2018; Published: March 30, 2018

\begin{abstract}
Mycobacterium avium subsp paratuberculosis (MAP) is classified under list B transmissible organisms signifying the public health concern and needs specific early diagnosis. Due to the cross reacting antigens of environmental mycobacterium and the diverse immune responses of individuals, cocktail of antigens capable of inducing strong immune response should be identified to improve serum-based methods of detection. Insertional sequence (IS900) was specific to par tuberculosis among the mycobacterium family, and among the IS900 elements, a nir A gene at locus 4 was putative to MAP and absent from the M. avium genome. In an attempt to identify the candidate antigens, nitrate reductase gene nir $A$ was successfully cloned and expressed in $E$. coli. In Western blot analysis strong immune reactivity was shown by the recombinant protein nitrate reductase with bovine anti MAP antibodies facilitates its use as a diagnostic candidate to improve the specificity of MAP diagnosis.
\end{abstract}

Key words- Mycobacterium-IS900-Recombinant antigen -diagnostic candidate.

Citation: Padmavathy C., et al., (2018) Immunoreactive Recombinant Nitrate Reductase Expressed by Nir A Gene of Mycobacterium avium sub sp paratuberculosis IS900 Element in E. coli. International Journal of Microbiology Research, ISSN: 0975-5276 \& E-ISSN: 0975-9174, Volume 10, Issue 3, pp.-1062-1065.

Copyright: Copyright@2018 Padmavathy C., et al., This is an open-access article distributed under the terms of the Creative Commons Attribution License, which permits unrestricted use, distribution and reproduction in any medium, provided the original author and source are credited.

DOI: http://dx.doi.org/10.9735/0975-5276.10.3.1062-1065

\section{Introduction}

Paratuberculosis (pTB) is a fatal inflammatory disease caused by Mycobacterium avium subsp. paratuberculosis (MAP) affecting both wild and domestic ruminants including cattle, sheep and goats. M. avium subsp. paratuberculosis, is difficult to diagnose due to closely related other $M$. avium subspecies. The principal difference between these pathogens and other members of the $M$. avium complex is the presence of 14-18 copies of the insertion element IS900 within M. avium subsp. paratuberculosis. Among them nir $A$ gene at locus 4 of IS900 is unique to M. avium subsp. paratuberculosis, and absent in other M. avium species [1]. Any immune response to its derived protein products would be indicative of specific infection. Expression and purification of these proteins will provide material suitable for ELISA and cell-mediated immunoassays [2]. The present study was focused on cloning and expression of recombinant Nir A product of IS900 in Escherichia coli and to assess the immunoreactivity with bovine anti MAP antibody.

\section{Materials and Method}

Bacterial strains and growth conditions: Mycobactin. J dependent Mycobacterium avium sub sp. paratuberculosis, K10 strains maintained at Department of Animal Biotechnology, Madras Veterinary college (TANUVAS) was used. Static culture of MAP was done by inoculating $1 \mathrm{ml}$ of glycerol stock of seed culture in $50 \mathrm{ml}$ of 7H9 medium (Difco) supplemented with $5 \mathrm{~g} /$ /iter glycerol,1g/liter BactoCasitone (225930-Difco, France), Middle brook enrichment medium oleic acid-albumindextrose catalase (OADC- cat no $211885 \mathrm{BD}-\mathrm{BBL}$ ) at the rate of $10 \%$, and 2 $\mathrm{mg} /$ liter mycobactin. J. After 8 weeks of growth, bacterial cells were pelleted by centrifugation and used for genomic DNA isolation by using DNAzol (cat no 10503-027, Invitrogen, USA). Mycobacterium phlei freeze dried culture was received from MTCC-cat no 1724 T (ATCC 11758, Chandigar) and cultivated in $7 \mathrm{H} 10$ agar (Difco) supplemented with 10\%OADC and from which cellular protein extracts were prepared and used to absorb cross-reacting serum antibodies prior to immunoblotting (preabsorption). E. coli strains, BL 21 and Nova blue were maintained by Department of Animal Biotechnology, Madras Veterinary college (TANUVAS) cultured in Luria Britani (LB) broth and stored as glycerol stock at-20 C. Plasmid vector pET 21b vector (Novagen, Germany) was used as cloning vector for PCR amplified gene insert, followed by its propagation in E. coli (Nova blue) and finally expression in E. coli BL21 (DE3). Bovine sera: MAP antibody positive and negative bovine sera samples tested by IDEXX ELISA kit were obtained from Central Referral Laboratory (IVPM, Ranipet). Amplification of Nir A gene of IS900: PCR amplification of Nir A gene from genomic DNA of MAP was done and was used as insert DNA for directional cloning in $p E T$ 21b vector. PCR was carried out by using Pfu polymerase (Novagen) with following gene specific primers having shine dalgarno sequence with Bam $\mathrm{HI}$ and Hind III restriction sites. FP: 5' GG GGAT CCA GAA GGA GAT ATA CAT ATG ACC ACC GCA CGT CCC 3' RP:5' ATG AAG CTT AGC TGC AGG TTT TCC CGG 3'. The PCR conditions included initial denaturation at $94^{\circ} \mathrm{C}$ for 5 mins and 35 cycles of template denaturation at $94^{\circ} \mathrm{C}$ for $45 \mathrm{sec}$, primer annealing at $64^{\circ} \mathrm{C}$ for 45 secs and primer extension at $72^{\circ} \mathrm{C}$ for $1.10 \mathrm{mins}$, followed by final extension at $72^{\circ} \mathrm{C}$ for $7 \mathrm{mins}$. The expected product size of 400 bp was gel eluted using Qiagen gel elution kit. The insert nucleotide sequence was determined by DNA sequencing (Eurofins Genomics India Pvt. Ltd) and analysed by NCBI BLAST for similar genes. The 
theoretical pl and instability/stability was calculated using ExPASy-ProtParam proteomic tool.

Cloning and expression of Nir A gene of IS900 was carried out as described by [3]. In brief the gel purified PCR product (Product size: 400bp) was ligated into pET 21b vector (Novagen) and transformed into competent cells of Escherichia coli (Nova Blue) prepared by treatment with ice cold CaCl2. Transformed clones were selected by using ampicillin as selectable marker. Plasmid DNA was isolated from the transformed clones using Qiaspin miniprep system (Qiagen) and the recombinants were confirmed by restriction enzyme double digestion using Bam $H I$ and $H$ ind III for insert release. The recombinant plasmids were transformed to BL21 E. coli expression vector. The recombinant plasmid insertion was confirmed by restriction enzyme double digestion. The recombinant $E$. coli carrying histidine tagged fusion gene of $\mathrm{pET} 21 \mathrm{~b}$ was induced for expression by the addition of $1.5 \mathrm{mM}$ IPTG (isopropyl thiogalactoside) when the OD at 600 reaches 0.5 and kept for overnight Incubation at $37^{\circ} \mathrm{C}$. The expressed proteins were analysed by $12.5 \%$ SDS- PAGE and checked for the solubility [4]. The expressed protein nitrate reductase was purified by Ni-NTA resin (Invitrogen) by column purification. In brief the cells were pelleted from $50 \mathrm{ml}$ of culture and lysed in $6 \mathrm{ml}$ of phosphate buffer containing $200 \mathrm{mM}$ of lysozyme with $1 \mathrm{mM}$ PMSF in ice bath for $30 \mathrm{~min}$. Freezing and thawing done thrice in $-80^{\circ} \mathrm{C}$ deep freezer followed by sonication in 5 cycles at 40 amplitude for $30 \mathrm{sec}$ in ice with $30 \mathrm{sec}$ interval. The cell lysate was clarified by centrifugation and the supernatant was used for Ni-NTA purification under non denaturing native purification condition as per manufacturer's guidelines. Elutes were checked for protein concentration by Bradford assay [5] using Bradford reagent (catlog 500-0205 Bio-rad). The molecular weight was checked by $12 \%$ SDS-PAGE with molecular weight marker (cat no: 161-0318 Bio-Rad).The immune-reactivity of the purified IS900 encoded nitrate reductase protein was determined by Western blot analysis. For blot preparation purified recombinant protein was loaded on to vertical gel electrophoresis using denaturing 12\%SDS- PAGE [6] at a concentration of $25 \mu \mathrm{g}$ per well. The separated proteins were transferred to nitrocellulose membrane by electro blotting [7] using Tris-glycine buffer containing $0.0375 \%$ SDS and $20 \%$ methanol.

\section{Results}

The present study was aimed at cloning and expression of IS900 Nir A gene encoding Nitrate reductase in $E$. coli. The targeted Nir A of insertion sequence was identified with full length ORF [Seq-1] for primer designing based on the known nucleotide sequence available in the $\mathrm{NCBI}$ database [GenBank ID:CAB96057].

Seq-1: Mycobacterium avium sub sp. paratuberculosis insertion sequence IS900, Locus 4, AJ250018.1, "nirA",

Protein: CAB96057

ATGACCACCGCACGTCCCGTCAAGACCCGCAACGAGGGTCAGTGGGCGCTG GGAGATCGCGAACCGCTCAACGACACCGAGAAGATCAAGCTGGCCGACGGG CCGCTGAACAGATCGGCGAGCGCATCATCAACGTCTACGCCAAGCAGGGTT TCGACAGCATCGACAAGTCCGACCTGCGCGGCCGCTTCCGGTGGATGGGCC TGTACACCCAACGCGAGCAGGGCTACGACGGCAGCTGGACCGGTGACGACA ACACCGACAAGATCGAAGCCAAGTACTTCATGATGCGGGTCCGCTCCGACG GCAAGGCGATGTCGGCGCACACCATGCGCACGCTCGGCCAGATCTCCACCG AATTCGCCCGCGACACCGCCGATATCAGCGACCGGGAAAACCTGCAGCT

The PCR in the presence of $3 \% \mathrm{DMSO}$, with annealing temperature at $64^{\circ} \mathrm{C}$ for 45sec was optimized. In PCR 400 bp amplicon was obtained as a distinct band representing the full length ORF of Nir A gene of insertional sequence 1 S900 revealed by $1.5 \%$ Agarose gel electrophoresis. [Fig-1]. Complete nucleotide sequence of the $400 \mathrm{bp}$ PCR amplified product found to have 100\% homology to MAP strains by NCBI blast analysis. Estimation of the theoretical pl: 9.92 and molecular weight: 22602.10 were obtained for Nitrate reductase protein of IS 900 containing 198 amino acid sequence, by using ExPASy-ProtParam tool. The instability index (II) is computed to be 64.3 classifies the protein as unstable and the estimated half-life is: $>10$ hours (Escherichia coli, in vivo).Ligation of the 400 bp gene insert with pET $21 \mathrm{~b}$ vector was done in a $20 \mu$ ligation reaction, containing restriction digested (Bam HI and Hind III) $250 \mathrm{ng}$ of insert and 50ng of plasmid at the ratio of $5: 1$ for $16 \mathrm{hrs}$ at $16^{\circ} \mathrm{C}$, and transformed into $100 \mu \mathrm{l}$ E.coli competent cells with heat shock given at $42^{\circ} \mathrm{C}$ for $50 \mathrm{sec}$. One clone was identified as recombinant by insert release after screening of five transformed clones with Restriction enzyme double digestion [Fig-2]. The recombinant protein expression induced by $1.5 \mathrm{mM}$ concentration of IPTG with overnight incubation gave high yield which was identified by increased band width in SDS-PAGE analysis. The molecular weight of the expressed protein was approximately 22.5 $\mathrm{kDa}$ [Fig-3]. The recombinant protein was found in the soluble fraction. The protein concentration of the Ni NTA purified elute [Fig-4] fraction was $0.168 \mu \mathrm{gg} / \mu \mathrm{l}$ by Bradford assay. Western blot analysis [Fig-5] with bovine anti MAP antibody positive serum showed immuno reactivity with the protein nitrate reductase of IS900 gene.

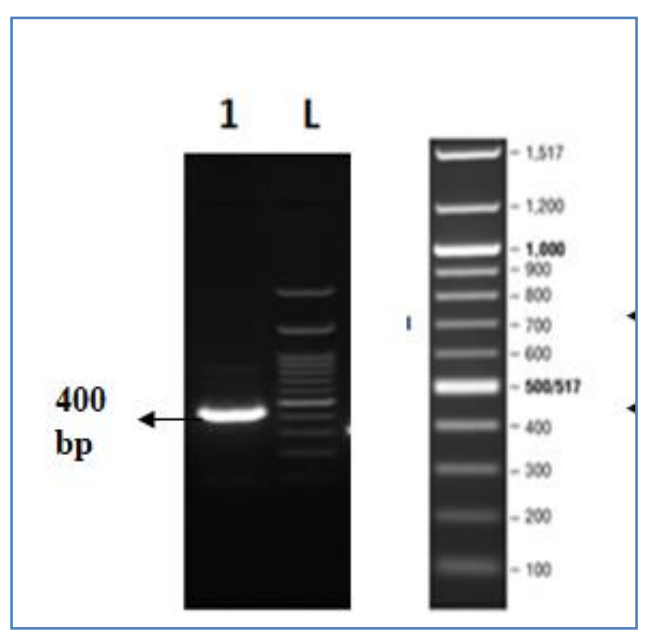

Fig 1- 1.5\% Agarose gel Electrophoresis showing PCR amplified Nir A gene of IS 900 Lane L: 100 bp Ladder; Lane 1: PCR product of 400 bp Nir A gene of $I S 900$

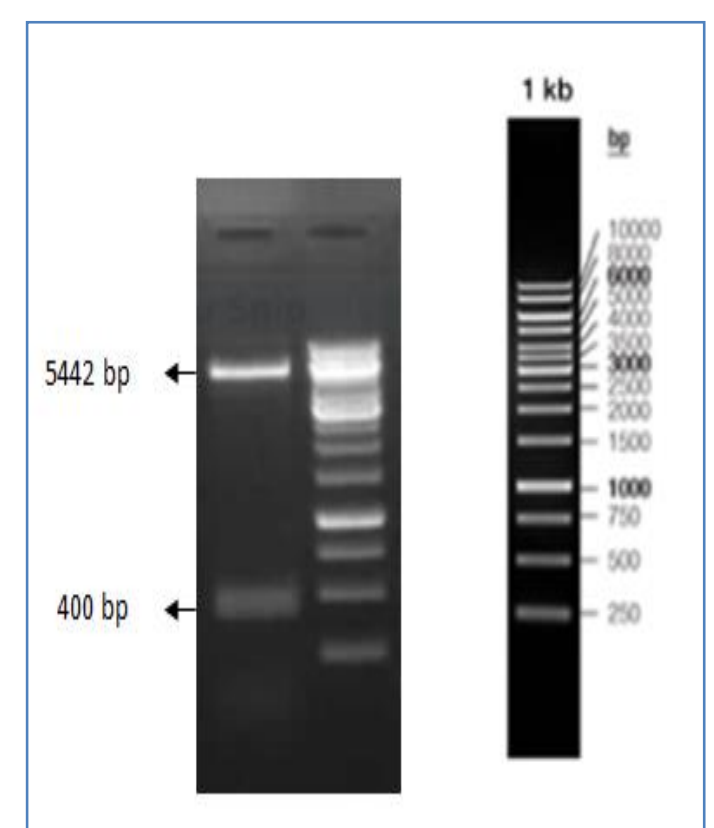

Fig 2- $0.8 \%$ Agarose gel electrophoresis of Restriction enzyme digestion of recombinant $\mathrm{pET}$ - Nir $A$ gene. Lane 1: 1Kb Ladder Lane 2: Restriction enzymes double digestion (Bam HI and Hind III) of recombinant plasmid 


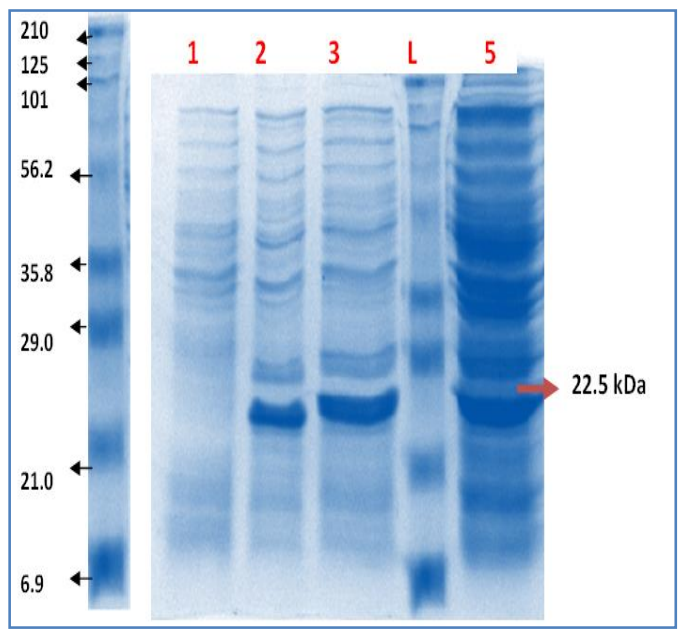

Fig 3- $12 \%$ SDS-Polyacrylamide gel electrophoresis of Nitrate Reductase protein of Nir A gene of IS900 at different hours of induction with IPTG. Lane 1: Un induced; Lane 2: 4 hrs of induction; Lane 3: $6 \mathrm{hrs}$ of induction; Lane L: Molecular weight marker; Lane 4; Overnight induction.

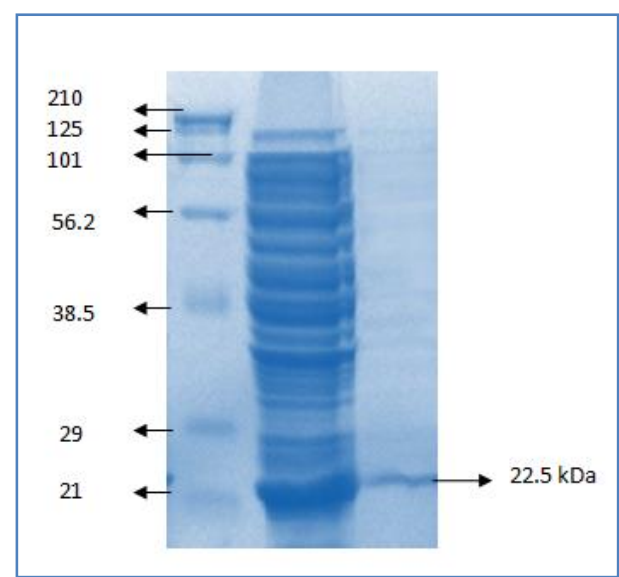

Fig 4- $12 \%$ SDS- Polyacrylamide gel electrophoresis analysis of Ni NTA purification of Nitrate Reductase protein of Nir A gene of $I S 900$ Lane 1: Molecular weight Marker; Lane 2: Unpurified; Lane 3: Purified Elute

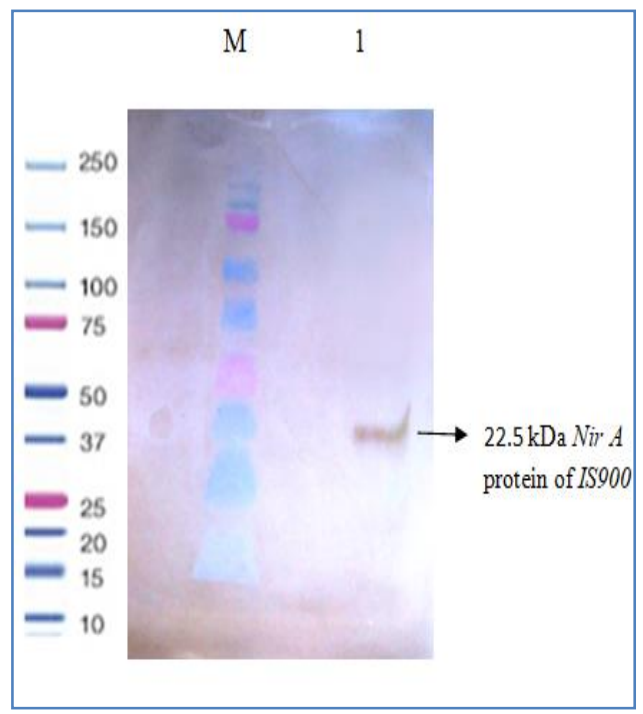

Fig 5- Immunoblotting of Nirate reductaseNir-A protein of IS900 Western blot analysis with Anti MAP antibody Positive bovine serum (Lane M: Molecular weight marker,Lane 1: Purified $22.5 \mathrm{kDa}$ protein).

\section{Discussion}

The main focus of the present study was production of recombinant nitrate reductase by cloning nir A gene of Mycobacterium avium subsp. paratuberculosis in E.coli. The molecular weight of the expressed recombinant protein was approximately of $22.5 \mathrm{kDa}$ in size by SDS-PAGE which is in agreement with the theoretical value of the expected protein. The strong immune-reactivity with bovine anti MAP antibodies in western blot analysis demonstrated the diagnostic potential of the recombinant protein encoded by Nir A gene of IS 900 elements of MAP. The present study supports the findings [2] that the components of $1 S 900$ elements may facilitate to improve the specificity of MAP diagnosis.

\section{Conclusion}

Development of MAP Diagnostics and Vaccine will require a cocktail of antigens due to the range of heterogeneous MHC molecules of out-bred animals [8] and to develope DIVA (Differentiation of Infected from Vaccinated Animals) strategy [9, 10]. Since $I S 900$ is unique to M. avium subsp. paratuberculosis, any immune response to its derived protein products would be indicative of specific infection as IS900 is the major genetic difference between M. avium subsp. paratuberculosis and $M$. avium. Hence the Nir A products can be a valuable component in development of MAP diagnostic with cocktail of antigens

Application of Research: There is a continuous research in identifying immunogenic proteins of MAP. Several antigens were identified and characterized for the development of candidate antigen with vaccine and diagnostic potential. Recombinant MAP antigens have various merits in terms of antigen production and human safety. Recombinant Nir A product of MAP showing immune reactivity with bovine antiMAP antibodies facilitates its use as a diagnostic candidate to improve the specificity of MAP diagnosis.

Research Category: Recombinant antigen production - Mycobacterium

$\begin{array}{lll}\text { Abbreviations } & & \\ \mathrm{Bp} & - & \text { Base pair } \\ \mathrm{CaCl} 2 & - & \text { Calcium chloride } \\ { }^{0} \mathrm{C} & - & \text { Degree centigrade } \\ \mathrm{DMSO} & - & \text { Dimethyl sulphoxide } \\ \mathrm{ELISA} & - & \text { Enzyme linked immunosorbant assay } \\ \mathrm{hrs} & - & \text { Hours } \\ \mathrm{IPTG} & - & \text { Isopropyl thiogalactoside } \\ \mathrm{kDa} & - & \text { Kilo dalton } \\ \mathrm{ng} & - & \text { Nanogram } \\ \mu \mathrm{Mg} & - & \text { Microgram } \\ \mu \mathrm{l} & - & \text { Microlitre } \\ \mathrm{MHC} & - & \text { Major histocompatability } \\ \mathrm{mins} & - & \text { Minutes } \\ \mathrm{mM} & - & \text { Millimolar } \\ \mathrm{MAP} & - & \text { Mycobacterium avium subsp. Par atuberculosis } \\ \text { OADC } & - & \text { Oleicacid-albumin-dextrosecatalase } \\ \text { PCR } & - & \text { Polymerase chain reaction } \\ \text { PMSF } & - & \text { Phenyl methyl sulfonyl fluoride } \\ \text { PTB } & - & \text { Paratuberculosis } \\ \text { SDS-PAGE } & - & \text { Sodium dodecyl sulphate-Poly acrylamide gel } \\ \text { electrophoresis } & & \end{array}$

Acknowledgement / Funding: Author thankful to Prof A. Raja, Department of Animal Biotechnology, Madras Veterinary College, Chennai, 600 007, Tamil Nadu for his technical support in bioinformatics. Author thankful to Institute of Veterinary Preventive Medicine (IVPM), Ranipet, 632402, Vellore, Tamil Nadu for kindly providing bovine serum samples tested for par tuberculosis antibodies. Author also thankful to Tamil Nadu Veterinary and Animal Sciences University, Chennai, 600 051, Tamil Nadu

*Research Guide or Chairperson of research: Prof Dr K VIJAYARANI University: Tamil Nadu Veterinary and Animal Sciences University, Chennai, 600051, Tamil Nadu 
Research project name or number: $\mathrm{PhD}$ Thesis

\section{Author Contributions: All author equally contributed}

Author statement: All authors read, reviewed, agree and approved the final manuscript

\section{Conflict of Interest: None declared}

Ethical approval: This article does not contain any studies with human participants or animals performed by any of the authors.

\section{References}

[1] Bull T.J., Taylor J.H., Pavlik I., El-Zaatari F.A.K and Tizard M. (2000) Microbiology, 146, 2185-2197

[2] El-Zaatari F. A. K., Naser S.A., Engstrand L., Hachem C.Y and Graham D.Y (1994) Current Microbiology, 29, 177-184

[3] Cho D., Shin S.J., Talaat A.M. and Collins M.T (2007) Protein Expression and Purification, 53, 411-420.

[4] Ausubel F.M., Brent R., Kingston R.E., Moore D.D., Seidman J.G., Smith J.A. and Struhl K. (eds.) (2003) Current Protocols in Molecular Biology, John Wiley \& Sons Inc, NY

[5] Bradford M.M (1976) Analytical Biochemistry, 72, 248-254

[6] Laemmli U. K. (1970) Nature, 227, 680-5

[7] Davies R.L., Wall R.A. and Borriello S.P (1990) Journal of Immunological Methods, 134 (2), 215-225

[8] Kumanan K., Vijayarani K., McDonough S., Chen L.H., Park S.U., Moreira M.A.S., Akey B., Huntley J., Chang C.F. and Chang Y.F (2009) Vaccine, 27,123-135

[9] Jayaraman S., Jain M., Dhama K., Singh S.V., Datta M., Jain N., Chaubey K.K., Gupta S., Aseril G.K., Khare N., Yadav P., Bhatia A.K and Sohall J.S (2016) Journal of Experimental Biology and Agricultural Science, 4(1), 1525

[10] Chaubey K.K., Gupta R.D., Gupta S., Singh S.V., Bhatia A.K and Jayaraman S. (2016) Journal of Veterinary Quarterly, 36(4), 203-227. 